Nurmala, T · A. Yuniarti · N. Syahfitri

\title{
Pengaruh berbagai dosis pupuk silika organik dan tingkat kekerasan biji terhadap pertumbuhan dan hasil tanaman hanjeli pulut (Coix lacryma jobi $\mathrm{L}$ ) genotip 37
}

\section{Effect of organic silica fertilizer dosage and seed hardness on the growth and yield of job's tears (Coix lacryma jobi $\mathrm{L}$.) pulut genotipe 37}

Diterima : 15 Juli 2016/Disetujui : 10 Agustus 2016 / Dipublikasikan : 30 Agustus 2016

CDepartment of Crop Science, Padjadjaran University

\begin{abstract}
This study aims to determine the organic silica fertilizer and seed hardness that can give the best effect on the growth and yield of job's tears (Coix lacryma jobi L.). Experiment was conducted from December 2015 to May 2016, in Ciparanje Experimental Field Faculty of Agriculture, Padjadjaran University, Jatinangor, West Java. The research used randomized block design (RBD) with six treatments and four replications, consistens of: Without organic silica (control) ; Organic silica dosage $(4,50 \mathrm{~g} /$ plant); (9,00 g/plant); (13,50 g/plant); (18,00 g/plant); $(22,50 \mathrm{~g} /$ plant $)$. The experiment obtains 24 experimental plots. The results showed that treatment without organic silica gave a significant effect on total biomassa, but non significant on plant height, number of leaves, number of tillers and leaf area index of job's tears plant. The results showed that treatment with silica organic at dosage $9,00 \mathrm{~g} /$ plant, 13,50 $\mathrm{g} /$ plant and 22,50 g/plant same with treatment without organic silica (control). The results using correlation analysis showed of correlation between brown tear's with seed hardness ( $r=$ $0,26)$. Where each increase in the intensity of brown tear's, will be followed by increase in the number of seed hardness.
\end{abstract}

Keywords : Job's tears (Coix lacryma- Jobi.L) .

Organic silica fertilizer · Dosage fertilizer

Sari Penelitian ini bertujuan untuk mengetahui dosis silika organik dan tingkat kekerasan biji yang dapat memberikan pengaruh terbaik

\footnotetext{
Dikomunikasikan oleh Aep Wawan Irwan

Nurmala, $\mathrm{T}^{1} \cdot$ A. Yuniarti ${ }^{1} \cdot$ N. Syahfitri ${ }^{2}$

${ }^{1}$ Staff Pengajar Program Studi Agroteknologi UNPAD

${ }^{2}$ Alumni Program Studi Agroteknologi UNPAD

Korespondensi: tati.nurmala@unpad.ac.id
}

terhadap pertumbuhan dan hasil tanaman hanjeli pulut (Coix lacryma- Jobi.L). Penelitian ini dilaksanakan pada bulan Desember 2015 sampai dengan bulan Mei 2016 di Kebun Percobaan Ciparanje Fakultas Pertanian Universitas Padjadjaran, Jatinangor, Sumedang. Rancangan percobaan yang digunakan adalah Rancangan Acak Kelompok (RAK) yang terdiri dari enam perlakuan dan empat kali ulangan, yaitu: Kontrol; Silika dosis (4,50 g/tanaman); (9,00 $\mathrm{g} /$ tanaman); (13,50 g/tanaman); (18,00 g/tanaman); (22,50 g/tanaman), sehingga diperoleh 24 petak percobaan. Hasil penelitian menunjukkan bahwa, perlakuan tanpa pupuk silika organik berpengaruh terhadap biomassa total tanaman hanjeli, tetapi tidak berpengaruh terhadap tinggi tanaman, jumlah daun, jumlah anakan dan indeks luas daun tanaman hanjeli. Hasil menunjukkan bahwa perlakuan dengan pupuk silika organik pada dosis 9,00 g/tanaman, 13,50 $\mathrm{g} /$ tanaman dan $22,50 \mathrm{~g} /$ tanaman memberikan hasil yang sama dengan perlakuan tanpa pupuk silika pada biomassa tanaman total. Hasil analisis korelasi menunjukkan adanya hubungan antara rendemen biji pecah kulit dengan kekerasan biji $(\mathrm{r}=0,26)$. Hasil tersebut mengindikasikan bahwa setiap peningkatan rendemen biji pecah kulit, akan diikuti kenaikan kekerasan biji.

Kata kunci: Hanjeli (Coix lacryma- Jobi.L) · Pupuk silika organik · Dosis pupuk

\section{Pendahuluan}

Pertumbuhan jumlah penduduk, khususnya di Indonesia dari tahun ke tahun semakin meningkat. Peningkatan jumlah penduduk ini 
berpengaruh terhadap kebutuhan akan pangan. Kendala yang dihadapi dalam pertumbuhan jumlah penduduk ialah permintaan pangan, khususnya beras yang terus meningkat, tetapi tidak diimbangi dengan produksinya. Salah satu solusi untuk menghadapi kelangkaan pangan yaitu dilakukan upaya diversifikasi pangan atau keanekaragaman pangan. Salah satu bahan pangan alternatif yang potensial sebagai pengganti beras untuk mencapai diversifikasi pangan ialah hanjeli (Coix lacryma- Jobi.L), hanjeli merupakan tanaman serealia dari familia Graminae yang memiliki potensi dan prospek baik untuk dikembangkan.

Hanjeli varietas mayeun atau yang sering disebut jali pulut merupakan varietas yang dibudidayakan, varietas mayeun memiliki kulit biji yang tipis dan mudah untuk dipecahkan, sehingga varietas ini sering dimanfaatkan sebagai bahan makanan dan obat tradisional (Nurmala, 1998). Kandungan protein, lemak, dan vitamin B1 pada hanjeli lebih tinggi dibandingkan beras, jagung, dan sorgum.

Upaya untuk meningkatkan produktivitas hanjeli salah satunya dapat dilakukan melalui aplikasi pemupukan yaitu pemberian pupuk silika. Silika dikenal dengan beneficial element yaitu unsur hara bermanfaat, meskipun syarat sebagai unsur hara esensial tidak terpenuhi, namun unsur Si telah lama diketahui sebagai unsur penting bagi beberapa tanaman pangan khususnya familia Graminae.

Hanjeli merupakan salah satu tanaman dari familia rerumputan (Graminae) yang menyerap unsur silika cukup banyak. Menurut hasil analisis tanaman hanjeli pada batang dan daun hanjeli mengandung silika sebesar 4,25 \%, sedangkan pada bagian biji hanjeli pulut mengandung silika sebesar 10,53\%, kulit biji hanjeli batu mengandung silika sebesar 16,60 \% dan arang sekam hanjeli mengandung silika sebesar 30,09\% (Laboratorium Kesuburan Tanah dan Nutrisi Tanaman, 2015). Unsur Si merupakan unsur kedua terbanyak setelah oksigen yang terdapat dalam kerak bumi dan unsur ke empat yang terpenting setelah NPK pada serealia. Pada praktek budidaya pertanian pemberian pupuk Si masih kurang diperhatikan, karena dianggap selalu tersedia dalam tanah. Unsur $\mathrm{N}, \mathrm{P}$, dan $\mathrm{K}$ umumnya dikembalikan ke dalam tanah melalui pemupukan, namun unsur $\mathrm{Si}$ dan unsur mikro tidak dikembalikan ke dalam tanah.

Pada pertumbuhan tanaman Si memiliki peranan penting, diantaranya yaitu $\mathrm{Si}$ dapat meningkatkan ketahanan tanaman terhadap ketidakseimbangan unsur hara, $\mathrm{Si}$ dapat meningkatkan ketersediaan unsur hara $\mathrm{P}$ dalam tanah, Si dapat mengurangi pengaruh $\mathrm{Mn}, \mathrm{Fe}$ dan $\mathrm{Al}$ yang sering terjadi pada tanah-tanah masam dan berdrainase buruk, Si dapat menguatkan batang sehingga tanaman tahan rebah, Si dapat mengurangi transpirasi, Si juga dapat mengurangi cekaman abiotik, seperti suhu, radiasi, cahaya, angin, air, dan kekeringan, serta meningkatkan resistensi tanaman terhadap cekaman biotik, sehingga dapat memperkuat jaringan tanaman dan lebih tahan terhadap serangan hama dan penyakit (Warta Penelitian dan Pengembangan Pertanian, 2011).

Dilihat dari peranan Si secara tidak langsung dapat meningkatkan produksi tanaman, sehingga pemupukan Si sebenarnya diperlukan untuk pertumbuhan tanaman. Tujuan dari penelitian ini ialah diharapkan dapat memperoleh dosis pupuk silika yang meningkatkan pertumbuhan dan hasil hanjeli (Coix lacrymaJobi.L).

\section{Bahan dan Metode}

Penelitian ini dilaksanakan di Kebun Percobaan Ciparanje Fakultas Pertanian, Universitas Padjadjaran, Jatinangor, Kabupaten Sumedang, Propinsi Jawa Barat. Percobaan dilakukan pada bulan Desember 2015 sampai dengan Mei 2016.

Bahan yang digunakan dalam percobaan ini ialah benih Hanjeli Pulut genotip 37 (benih dari koleksi Laboratorium Produksi dan Pemuliaan Tanaman Fakultas Pertanian Universitas Padjadjaran). Pupuk silika organik curah yang berasal dari arang kulit hanjeli yang telah disosoh dengan dosis silika 4,50; 9,00; 13,50; 18,00, dan 22,50 g/polybag dan kontrol (tanpa silika). Tanah sebanyak $1.920 \mathrm{~kg}$, pupuk kotoran sapi dengan dosis 5 ton/ha, pupuk NPK majemuk dengan dosis $200 \mathrm{~kg} / \mathrm{ha}$ dan pupuk urea dengan dosis $100 \mathrm{~kg} / \mathrm{ha}$. Peralatan yang digunakan dalam percobaan ini ialah pengisian media tanam (garu kored, parang), polybag, tugal, label, ember, alat ukur (penggaris/ meteran), timbangan, kamera, alat-alat laboratorium untuk analisa kimia, alat tulis, mesin penyosoh dan mesin pembuat arang).

Metode penelitian yang digunakan adalah metode Rancangan Acak Kelompok (RAK) sederhana, yaitu dengan dosis silika organik. Perlakuan terdiri dari enam perlakuan dan empat ulangan, sehingga terdapat 24 satuan percobaan. Perlakuan yang diberikan yaitu : 
$\mathrm{A}=$ Tanpa silika organik (kontrol)

$\mathrm{B}=$ Silika organik $(4,50 \mathrm{~g} /$ tanaman $)$

$\mathrm{C}=$ Silika organik $(9,00 \mathrm{~g} /$ tanaman $)$

$\mathrm{D}=$ Silika organik $(13,50 \mathrm{~g} /$ tanaman $)$

$\mathrm{E}=$ Silika organik (18,00 g/ tanaman)

$\mathrm{F}=$ Silika organik $(22,50 \mathrm{~g} /$ tanaman $)$

Analisis data percobaan akan dilakukan berdasarkan model Rancangan Acak Kelompok. Uji $F$ dilakukan dengan menguji peluang dari variasi di antara nilai rata-rata perlakuan untuk mengetahui minimal sepasang perlakuan yang berbeda nyata. Jika pada taraf uji $5 \%$ nilai $\mathrm{F}_{\text {hitung }}$ $>\mathrm{F}$ tabel maka dapat dinyatakan bahwa terdapat minimal sepasang perlakuan adalah berbeda nyata. Jika dari analisis ragam nilai $F$ hitung $>F$ tabel, dilanjutkan dengan uji lanjut Duncan pada taraf 5\% untuk menguji perbedaan antar masing-masing nilai rata-rata perlakuan.

Persiapan media tanam dilakukan dengan menyiapkan tanah yang dihaluskan dan diayak, kemudian dicampur rata dengan pupuk kandang. Tanah yang sudah tercampur, selanjutnya dimasukkan ke dalam polybag berukuran $50 \times 50 \mathrm{~cm}$ dengan volume tanah 20 kg setiap polybagnya. Perlakuan sebanyak 24 satuan percobaan, dimana setiap satuan percobaan terdiri dari empat tanaman hanjeli.

Benih ditanam di dalam polybag, dengan jarak antar polybag $10 \mathrm{~cm}$, jarak antar perlakuan $70 \mathrm{~cm}$ dan jarak antar ulangan $1 \mathrm{~m}$. Lubang tanam dibuat menggunakan tugal dengan kedalaman 5,0 cm, lalu masukkan Furadan 3GR ditaburkan ke dalam lubang lalu di tutup dengan tanah, kemudian memasukkan benih dengan jumlah tiga biji setiap polybag lalu di tutup dengan tanah. Pada saat umur 4 MST dilakukan dan disisakan satu tanaman.

Pemberian pupuk kotoran sapi diberikan satu kali sebagai pupuk dasar, pada saat awal yaitu 5 ton/ha. Pupuk kandang sapi yang digunakan sebagai pupuk dasar, diberikan pada saat seminggu sebelum tanam dengan dosis 5 ton/ha. Pemberian pupuk NPK majemuk dengan dosis $200 \mathrm{~kg} / \mathrm{ha}$. Pemberian pupuk NPK majemuk diberikan dua kali yaitu pada saat 21 hst dan pada 90 hst pemberian pupuk urea 60 hst dengan dosis $100 \mathrm{~kg} / \mathrm{ha}$. Pupuk yang digunakan pada saat aplikasi perlakuan menggunakan pupuk silika organik yang berasal dari sosohan biji hanjeli pulut yang telah diarangkan. Pengapilkasian pupuk silika organik diberikan pada saat tanaman berumur 35 hst. Dosis untuk pupuk silika organik sebanyak 4,50; 9,00; 13,50; 18,00 dan 22,50 $\mathrm{g} /$ tanaman dan kontrol.
Pemeliharaan tanaman hanjeli meliputi penyiraman, penyulaman, penyiangan gulma, pengendalian gulma, hama dan penyakit. Penyiraman dilakukan setiap hari apabila tidak turun hujan sampai hanjeli tumbuh. Penyulaman dilakukan 21-24 hst. Penyiangan dulma dilakukan setiap ada yang tumbuh sepanjang percobaan penelitian dilaksanakan. Pengendalian gulma dilakukan secara mekanis dengan menggunakan tangan atau kored. Pengandalian hama dan penyakit dilakukan menggunakan pestisida dan disesuaikan dengan hama dan penyakit yang menyerang.

Hanjeli dipanen ketika tanaman telah mencapai matang fisiologis, yaitu sekitar 165 HST. Ciri-ciri tanaman hanjeli siap panen yang ditandai dengan biji yang telah berisi, keras apabila dipijit. Warna biji hanjeli setelah matang berwarna putih sampai coklat dan ungu (Rahmawati, 2003). Pengamatan penunjang merupakan pengamatan yang digunakan untuk memperkuat dan memperjelas hasil percobaan serta untuk menunjang pengamatan utama. Pengamatan dalam percobaan ini meliputi pengamatan karakter kuantitatif dan kualitatif menggunakan semua tanaman hanjeli yang tumbuh di setiap polybag. Komponen pertumbuhan dan hasil meliputi tinggi tanaman (cm), jumlah daun, jumlah anakan per rumpun, indeks luas daun (ILD) dan biomassa tanaman total, jumlah srisip per rumpun, jumlah malai per batang, jumlah biji per rumpun, dan nisbah pupus akar (NPA). Hasil meliputi bobot biji per perlakuan $(\mathrm{g})$, bobot 100 butir $(\mathrm{g})$, rendemen biji pecah kulit (RBPK) (\%), kekerasan biji dan indeks panen.

\section{Hasil dan Pembahasan}

Tinggi Tanaman. Pengukuran tinggi tanaman hanjeli dilakukan pada saat tanaman berumur 11 MST. Data analisis dengan menggunakan uji F pada taraf kepercayaan 5\%.

Berdasarkan hasil analisis data statistik pada Tabel 3 diketahui bahwa pemberian pupuk silika organik menunjukan pengaruh yang tidak berbeda nyata terhadap tinggi tanaman pada umur 11 MST. Hal ini diduga karena pupuk silika organik belum sepenuhnya terlarut pada tanaman hanjeli, di dalam tanah masih terlihat arang kulit hanjeli yang masih utuh, meskipun hasil menunjukkan bahwa perlakuan pemberian pupuk silika organik menghasilkan tinggi tanaman yang lebih baik dibandingkan dengan 
perlakuan tanpa pupuk silika organik (kontrol). Pemberian pupuk silika organik juga secara tidak langsung meningkatkan ketersediaan $\mathrm{P}$ di dalam tanah, sehingga $P$ tersedia bagi tanaman yang disajikan pada Tabel 2.

Tabel 1. Pengaruh Pupuk Silika Organik terhadap Tinggi Tanaman Hanjeli 11 MST.

\begin{tabular}{cc}
\hline Perlakuan & Tinggi Tanaman $(\mathrm{cm})$ \\
\hline $\mathrm{A}$ & $120,56 \mathrm{a}$ \\
$\mathrm{B}$ & $122,12 \mathrm{a}$ \\
$\mathrm{C}$ & $126,81 \mathrm{a}$ \\
$\mathrm{D}$ & $123,75 \mathrm{a}$ \\
$\mathrm{E}$ & $121,25 \mathrm{a}$ \\
$\mathrm{F}$ & $125,50 \mathrm{a}$ \\
\hline \hline
\end{tabular}

Keterangan : Nilai rata-rata yang diikuti oleh huruf yang sama tidak berbeda nyata menurut uji jarak berganda Duncan pada taraf $5 \%$

Sejalan dengan pernyataan Martanto (2001), Si berperan dalam memperbaiki ketegakan tanaman, sehingga terjadi peningkatan intersepsi cahaya matahari yang digunakan selama proses fotosintesis. Dengan demikian, diduga perlakuan dosis pupuk silika yang tertinggi memicu pertumbuhan tinggi tanaman jika dibandingkan dengan perlakuan tanpa pupuk silika (kontrol). Tinggi tanaman merupakan indikator pertumbuhan maupun sebagai parameter untuk mengukur dan mengetahui pengaruh perlakuan yang diberikan dan sebagai indikator untuk mengetahui pengaruh lingkungan. Adanya pertambahan tinggi tanaman merupakan bentuk peningkatan penambahan sel-sel akibat adanya asimilat yang meningkat.

Jumlah Daun. Pengamatan jumlah daun dilakukan pada tanaman hanjeli umur 11 MST. Daun merupakan organ untuk proses fotosintesis pada tanaman. Pertumbuhan jumlah daun dapat dijadikan salah satu parameter untuk pertumbuhan vegetatif untuk melihat pengaruh perlakuan pupuk silika organik.

Berdasarkan hasil analisis ragam menunjukkan bahwa tidak terdapat pengaruh nyata terhadap jumlah daun hanjeli pada umur 11 MST. Hal ini diduga karena pupuk silika organik belum sepenuhnya terlarut pada tanaman hanjeli, meskipun hasil menunjukkan bahwa perlakuan pemberian pupuk silika organik menghasilkan jumlah daun yang lebih baik dibandingkan dengan perlakuan tanpa pupuk silika organik (kontrol). Hal tersebut diduga pemberian pupuk silika organik membantu pertumbuhan jumlah daun dan secara tidak langsung meningkatkan keterse- diaan $\mathrm{P}$ di dalam tanah yang disajikan pada Tabel 2.

Tabel 2. Pengaruh Pupuk Silika Organik terhadap Jumlah Daun Tanaman Hanjeli 5, 7, 9 dan 11 MST.

\begin{tabular}{ccccc}
\hline \hline Perlakuan & \multicolumn{4}{c}{ Jumlah Daun } \\
\cline { 2 - 5 } & 5 MST & 7 MST & 9 MST & 11 MST \\
\hline A & $15,37 \mathrm{a}$ & $30,25 \mathrm{a}$ & $45,75 \mathrm{a}$ & $64,94 \mathrm{a}$ \\
$\mathrm{B}$ & $16,25 \mathrm{a}$ & $34,88 \mathrm{a}$ & $50,50 \mathrm{a}$ & $68,69 \mathrm{a}$ \\
$\mathrm{C}$ & $14,94 \mathrm{a}$ & $35,13 \mathrm{a}$ & $49,69 \mathrm{a}$ & $67,31 \mathrm{a}$ \\
$\mathrm{D}$ & $15,94 \mathrm{a}$ & $31,00 \mathrm{a}$ & $44,50 \mathrm{a}$ & $66,50 \mathrm{a}$ \\
$\mathrm{E}$ & $16,56 \mathrm{a}$ & $35,69 \mathrm{a}$ & $48,56 \mathrm{a}$ & $66,75 \mathrm{a}$ \\
$\mathrm{F}$ & $16,20 \mathrm{a}$ & $31,38 \mathrm{a}$ & $45,81 \mathrm{a}$ & $63,69 \mathrm{a}$ \\
\hline \hline
\end{tabular}

Keterangan : Nilai rata-rata yang diikuti oleh huruf yang sama tidak berbeda nyata menurut uji jarak berganda Duncan pada taraf 5\%.

Jumlah Anakan per Rumpun. Hasil analisis sidik ragam mengenai jumlah anakan pada hanjeli umur 11 MST.

Tabel 3. Pengaruh Pupuk Silika Organik terhadap Jumlah Anakan Tanaman Hanjeli 11 MST.

\begin{tabular}{cc}
\hline \hline Perlakuan & Jumlah Anakan \\
\hline A & $11,31 \mathrm{a}$ \\
B & $12,63 \mathrm{a}$ \\
C & $11,50 \mathrm{a}$ \\
D & $11,75 \mathrm{a}$ \\
E & $11,88 \mathrm{a}$ \\
F & $11,13 \mathrm{a}$ \\
\hline \hline
\end{tabular}

$\overline{\text { Keterangan : Nilai rata-rata yang diikuti oleh huruf }}$ yang sama tidak berbeda nyata menurut uji jarak berganda Duncan pada taraf 5\%.

Berdasarkan hasil analisis data statistik pada Tabel 2 diketahui bahwa pemberian pupuk silika organik menunjukan pengaruh yang tidak berbeda nyata pada setiap perlakuan terhadap jumlah daun pada umur 11 MST. Hal ini diduga karena pupuk silika organik belum sepenuhnya larut dalam tanah, meskipun secara nyata secara tidak langsung meningkatkan ketersediaan $p$ di dalam tanah dibandingkan dengan perlakuan tanpa pupuk silika organik (kontrol) yang disajikan pada Tabel 2.

Faktor lain yang mempengaruhi tidak berbeda nyata yaitu unsur hara yang dibutuhkan untuk membentuk anakan pada tanaman hanjeli sudah tercukupi, sehingga pemberian pupuk silika organik tidak berpengaruh nyata pada jumlah anakan. Sejalan dengan pernyataan Yelis, 2011, bahwa jumlah tunas anakan lebih ditentukan oleh varietas yang digunakan sama hal nya jumlah srisip pada tanaman hanjeli. Anakan 
mulai terbentuk pada saat tanaman berumur 10 HST dan mencapai jumlah maksimalnya pada umur 50-60 HST.

Indeks Luas Daun. Indeks luas daun merupakan rasio antara luas daun dengan luas areal tanaman. Berdasarkan hasil analisis data statistik pada Tabel 4 diketahui bahwa pemberian pupuk silika organik menunjukan pengaruh yang tidak berbeda nyata pada setiap perlakuan terhadap indeks luas daun pada hanjeli umur 12 MST. Hasil analisis uji F pada taraf kepercayaan 5\% dapat dilihat pada Tabel 3.

Tabel 4. Pengaruh Pupuk Silika Organik terhadap Indeks Luas Daun Tanaman Hanjeli 12 MST.

\begin{tabular}{cc}
\hline \hline Perlakuan & Indeks Luas Daun \\
\hline A & $5,22 \mathrm{a}$ \\
B & $5,53 \mathrm{a}$ \\
C & $5,64 \mathrm{a}$ \\
D & $5,47 \mathrm{a}$ \\
E & $5,51 \mathrm{a}$ \\
F & $4,99 \mathrm{a}$ \\
\hline \hline
\end{tabular}

$\overline{\text { Keterangan : Nilai rata-rata yang diikuti oleh huruf }}$ yang sama tidak berbeda nyata menurut uji jarak berganda Duncan pada taraf 5\%.

Faktor yang mempengaruhi tidak berbeda nyata terhadap indeks luas daun tanaman hanjeli yaitu kerapatan tanaman. Kerapatan tanaman diakibatkan jarak tanam yang terlalu sempit, sehingga semakin sedikitnya radiasi cahaya yang sampai ke lapisan daun bagian bawah sampai ke tanah. Penyerapan cahaya akan lebih maksimal pada daun yang lebih luas, oleh karena itu kerapatan tanaman memicu nilai indeks luas daun yang tidak berbeda nyata. Pupuk silika organik yang belum sepenuhnya terlarut merupakan salah satu faktor yang menyebabkan tidak berbeda nyata, meskipun secara nyata pemberian pupuk silika organik meningkatkan kertsediaan $\mathrm{P}$ di dalam tanah sehingga tersedia bagi tanaman yang disajikan pada Tabel 4.

Biomassa Tanaman Total. Berdasarkan hasil analisis data statistik statistik pada Tabel 5 diketahui bahwa pemberian pupuk silika organik memberikan pengaruh yang berbeda nyata terhadap biomassa tanaman total hanjeli.

Hasil analisis menunjukkan bahwa perlakuan A memberikan pengaruh yang berbeda nyata dengan perlakuan $\mathrm{E}$ dan $\mathrm{B}$ namun tidak berbeda nyata dengan perlakuan $\mathrm{C}, \mathrm{D}$, dan $\mathrm{F}$. Dapat dilihat dari Tabel 5 perlakuan tanpa silika (kontrol) memiliki bobot biomassa lebih besar jika dibandingkan dengan perlakuan dengan pemberian pupuk silika organik. Diduga faktor yang mempengaruhi perlakuan tanpa silika (kontrol) lebih tinggi dibandingkan dengan perlakuan dengan pemberian pupuk silika organik ialah pada hasil analisis tanah awal kandungan Si dalam tanah sudah cukup tinggi yaitu sekitar $22,24 \%$, sehingga dapat diduga tidak terdapat pengaruh yang nyata pada tanah yang cukup Si jika diberikan pupuk silika organik.

Tabel 5. Pengaruh Pupuk Silika Organik terhadap Biomassa Tanaman Total Tanaman Hanjeli.

\begin{tabular}{cc}
\hline \hline Perlakuan & Biomassa $(\mathrm{g})$ \\
\hline A & $772,89 \mathrm{c}$ \\
B & $499,96 \mathrm{ab}$ \\
C & $688,56 \mathrm{bc}$ \\
D & $583,40 \mathrm{abc}$ \\
E & $458,43 \mathrm{a}$ \\
F & $637,36 \mathrm{abc}$ \\
\hline \hline
\end{tabular}

Keterangan : Nilai rata-rata yang diikuti oleh huruf yang sama tidak berbeda nyata menurut uji jarak berganda Duncan pada taraf 5\%.

Pemberian pupuk silika organik meskipun tidak berbeda nyata, tetapi secara tidak langsung meningkatkan ketersediaan $\mathrm{P}$ di dalam tanah, sehingga tersedia bagi tanaman. Hal ini sejalan dengan pernyataan Sudibyo (2008) pemberian Si pada tanah-tanah di daerah ropika secara nyata dapat meningkatkan ketersediaan $\mathrm{P}$ dalam tanah. Faktor lain yang juga mempengaruhi ialah ketersediaan air lebih mempengaruhi pertumbuhan dan perkembangan suatu tanaman terhadap berat kering tumbuhan. Menurut Solichatun (2005), pertumbuhan suatu tumbuhan dapat diukur melalui laju pertumbuhan relatifnya dan berat kering tumbuhan atau yang disebut biomassa total.

Biomassa tumbuhan meliputi hasil fotosintesis, serapan unsur hara dan air. Bobot kering brangkasan yang tinggi dapat diperoleh apabila tanaman tumbuh dan berkembang dengan normal dan optimal. Berat kering menunjukkan produktivitas suatu tanaman karena $90 \%$ hasil fotosintesis terdapat dalam bentuk berat kering (Gardner et al., 1991). Tanaman selama hidupnya membentuk biomassa yang digunakan untuk membentuk bagian-bagian tubuhnya. Menurut Sitompul dan Guritno (1995), biomassa tanaman meliputi semua bahan tanaman yang secara kasar berasal dari hasil fotosinteisis. Pengukuran biomassa tanaman total merupakan parameter yang digunakan sebagai indikator pertumbuhan tanaman. Pada penelitian ini biomassa tanaman 
diukur dengan cara menimbang bahan tanaman yang sudah dikering oven.

Jumlah Srisip per Rumpun. Pengamatan jumlah srisip dilakukan pada saat tanaman umur 16 MST. Berdasarkan hasil analisis data statistik yang disajikan pada Tabel 4 menunjukkan pengaruh yang tidak berbeda nyata pada setiap perlakuan terhadap jumlah srisip per rumpun.

Tabel 6. Pengaruh Pupuk Silika Organik terhadap Jumlah Srisip per Rumpun Tanaman Hanjeli.

\begin{tabular}{cc}
\hline \hline Perlakuan & Jumlah Srisip per Rumpun \\
\hline A & $73,44 \mathrm{a}$ \\
B & $64,75 \mathrm{a}$ \\
C & $67,19 \mathrm{a}$ \\
D & $71,38 \mathrm{a}$ \\
E & $64,13 \mathrm{a}$ \\
F & $64,94 \mathrm{a}$ \\
\hline \hline
\end{tabular}

$\overline{\text { Keterangan : Nilai rata-rata yang diikuti oleh huruf }}$ yang sama tidak berbeda nyata menurut uji jarak berganda Duncan pada taraf 5\%.

Pemberian pupuk silika organik tidak berpengaruh terhadap jumlah srisip tanaman hanjeli. Pada Tabel 4 perlakuan yang memiliki jumlah srisip paling baik ialah pada perlakuan tanpa pupuk silika organik (kontrol). Hal ini dapat diduga bahwa jumlah srisip tidak dipengaruhi oleh penambahan unsur hara $\mathrm{Si}$, melainkan faktor genetik dari tanaman itu sendiri. Menurut Yelis (2011), jumlah srisip lebih ditentukan oleh varietas yang digunakan, sehingga pemberian pupuk silika tidak memicu peningkatan jumlah srisip tanaman hanjeli.

Faktor lain yang juga mempengaruhi perlakuan tanpa pupuk silika organik (kontrol) lebih tinggi dibandingkan dengan perlakuan dengan pemberian pupuk silika organik ialah pada hasil analisis tanah awal kandungan Si dalam tanah sudah cukup tinggi yaitu sekitar 22,24\%, sehingga dapat diduga tidak terdapat pengaruh yang nyata pada tanah yang cukup Si jika diberikan pupuk silika organik. Pemberian pupuk silika organik secara tidak langsung meningkatkan ketersediaan $\mathrm{P}$ di dalam tanah sehingga tersedia bagi tanaman meskipun hasil analisis statistika tidak menunjukkan pengaruh nyata.

Jumlah Malai per Batang. Pengamatan jumlah malai dilakukan pada saat menjelang panen. Perhitungan jumlah malai dilakukan dengan menghitung malai pada batang utama yang mewakili semua anakan per rumpun. Hasil analisis uji $\mathrm{F}$ pada taraf kepercayaan $5 \%$ yang disajikan pada Tabel 7.
Pemberian pupuk silika organik menunjukkan pengaruh yang tidak berbeda nyata terhadap jumlah malai per batang utama. Hal ini diduga karena pupuk silika organik belum sepenuhnya terlarut pada tanaman hanjeli, meskipun hasil menunjukkan bahwa perlakuan pemberian pupuk silika organik menghasilkan jumlah malai per batang utama yang lebih baik dibandingkan dengan perlakuan kontrol.

Tabel 7. Pengaruh Pupuk Silika terhadap Jumlah Malai per Batang Utama Tanaman Hanjeli.

\begin{tabular}{cc}
\hline \hline Perlakuan & $\begin{array}{c}\text { Jumlah Malai per batang } \\
\text { utama }\end{array}$ \\
\hline A & $43,06 \mathrm{a}$ \\
B & $50,63 \mathrm{a}$ \\
C & $45,06 \mathrm{a}$ \\
D & $41,00 \mathrm{a}$ \\
E & $42,23 \mathrm{a}$ \\
F & $57,81 \mathrm{a}$ \\
\hline \hline
\end{tabular}

Keterangan : Nilai rata-rata yang diikuti oleh huruf yang sama tidak berbeda nyata menurut uji jarak berganda Duncan pada taraf 5\%.

Hal ini sejalan dengan hasil penelitian Amrullah (2015), yaitu pemberian silika pada tanaman padi dapat meningkatkan jumlah malai dan panjang malai yang dihasilkan. Kekurangan atau tidak adanya pemberian Si pada tanaman padi dapat mengakibatkan meningkatnya jumlah gabah hampa, menurunkan bobot gabah, menurunkan panjang malai, menurunkan jumlai malai dan menurunkan jumlah gabah per malai (Ma dan Takashi, 2002). Silika secara tidak langsung meningkatkan ketersediaan $\mathrm{P}$ dalam tanah, sehingga tersedia bagi tanaman Silika juga dapat meningkatkan translokasi $\mathrm{P}$ ke malai, sehingga peran P lebih optimal bagi tanaman. Hal ini sejalan dengan pernyataan Sudibyo (2008) pemberian Si pada tanah-tanah di daerah ropika secara nyata dapat meningkatkan ketersediaan P dalam tanah.

Jumlah Biji per Rumpun. Data analisis dengan menggunakan uji $F$ pada taraf kepercayaan $5 \%$.

Berdasarkan hasil analisis data statistik pada Tabel 8 diketahui bahwa pemberian pupuk silika organik tidak berpengaruh nyata terhadap jumlah biji per rumpun. Hal ini diduga karena jumlah biji per rumpun lebih dipengaruhi oleh jumlah anakan dan jumlah malai yang dihasilkan, sehingga pemberian pupuk silika tidak begitu berpengaruh terhadap jumlah biji per rumpun tanaman hanjeli.

Diduga faktor yang mempengaruhi perlakuan tanpa silika (kontrol) lebih tinggi diban- 
dingkan dengan perlakuan dengan pemberian pupuk silika organik ialah pada hasil analisis tanah awal kandungan Si dalam tanah sudah cukup tinggi yaitu sekitar 22,24\%, sehingga dapat diduga tidak terdapat pengaruh yang nyata pada tanah yang cukup Si jika diberikan pupuk silika organik.

Tabel 8. Pengaruh Pupuk Silika Organik terhadap Jumlah Biji per Rumpun Tanaman Hanjeli.

\begin{tabular}{cc}
\hline \hline Perlakuan & Jumlah Biji per Rumpun \\
\hline A & $1578,13 \mathrm{a}$ \\
B & $1458,31 \mathrm{a}$ \\
C & $1473,81 \mathrm{a}$ \\
D & $1473,38 \mathrm{a}$ \\
E & $1471,38 \mathrm{a}$ \\
F & $1373,19 \mathrm{a}$ \\
\hline \hline
\end{tabular}

$\overline{\text { Keterangan : Nilai rata-rata yang diikuti oleh huruf }}$ yang sama tidak berbeda nyata menurut uji jarak berganda Duncan pada taraf $5 \%$.

Faktor lainnya yang menyebabkan tidak ada perbedaan nyata yaitu penyerapan unsur $\mathrm{P}$ yang kurang berjalan dengan optimal, meskipun secara tidak langsung pemberian pupuk silika organik meningkatkan ketersediaan P di dalam tanah. Menurut Nyapka et al (1988), menyatakan bahwa fosfor penting bagi tumbuhan pada proses pembentukan biji dan pada saat awal pematangan terutama pada tanaman serealia.

Nisbah Pupus Akar (NPA). Hasil analisis data pengaruh pemberian pupuk silika organik terhadap nisbah pupus akar tanaman hanjeli disajikan Tabel 9, diketahui bahwa pemberian pupuk silika organik menunjukkan pengaruh yang tidak berbeda nyata terhadap nisbah pupus akar tanaman hanjeli.

Tabel 9. Pengaruh Pupuk Silika Organik terhadap Nisbah Pupus Akar Tanaman Hanjeli.

\begin{tabular}{cc}
\hline \hline Perlakuan & Nisbah Pupus Akar \\
\hline A & $2,79 \mathrm{a}$ \\
$\mathrm{B}$ & $2,84 \mathrm{a}$ \\
$\mathrm{C}$ & $2,55 \mathrm{a}$ \\
$\mathrm{D}$ & $2,75 \mathrm{a}$ \\
$\mathrm{E}$ & $2,43 \mathrm{a}$ \\
$\mathrm{F}$ & $2,60 \mathrm{a}$ \\
\hline \hline
\end{tabular}

Keterangan : Nilai rata-rata yang diikuti oleh huruf yang sama tidak berbeda nyata menurut uji jarak berganda Duncan pada taraf 5\%.

Hasil menunjukkan bahwa pada perlakuan dengan pupuk silika organik pertumbuhan tanaman lebih ke arah pembentukan pupus dibandingkan dengan pembentukan akar. Hal ini diduga karena pada hasil analisis tanah awal kandungan Si dalam tanah sudah cukup tinggi yaitu sekitar 22,24\%, sehingga tidak terdapat pengaruh yang nyata pada tanah yang cukup $\mathrm{Si}$ jika diberikan pupuk silika organik. Menurut Nurmala dan Irwan (2007), nisbah pupus akar yang sideal untu tanaman pangan bernilai 3 . Pada hasil percobaa rata-rata nilai nisbah pupus akar bernilai 2,43-2,84. Dapat disimpulkan bahwa distribusi fotosintat lebih ke arah pupus dibandingkan dengan akar.

Bobot Biji per Rumpun \& Bobot Biji per Perlakuan. Hasil analisis uji lanjut Duncan pada taraf 5\% mengenai pengaruh pupuk silika organik terhadap bobot biji per rumpun dan bobot biji per perlakuan tercantum pada Tabel 10 .

Tabel 10. Pengaruh Pupuk Silika Organik terhadap Bobot biji per rumpun dan Bobot biji per perlakuan Tanaman Hanjeli.

\begin{tabular}{ccc}
\hline \hline Perlakuan & $\begin{array}{c}\text { Bobot biji per } \\
\text { rumpun }(\mathrm{g})\end{array}$ & $\begin{array}{c}\text { Bobot biji per } \\
\text { perlakuan }(\mathrm{g})\end{array}$ \\
\hline $\mathrm{A}$ & $241,31 \mathrm{a}$ & $965,25 \mathrm{a}$ \\
$\mathrm{B}$ & $184,00 \mathrm{a}$ & $736,00 \mathrm{a}$ \\
$\mathrm{C}$ & $183,00 \mathrm{a}$ & $765,75 \mathrm{a}$ \\
$\mathrm{D}$ & $213,25 \mathrm{a}$ & $853,00 \mathrm{a}$ \\
E & $194,50 \mathrm{a}$ & $778,00 \mathrm{a}$ \\
F & $206,17 \mathrm{a}$ & $831,43 \mathrm{a}$ \\
\hline \hline
\end{tabular}

$\overline{\text { Keterangan : Nilai rata-rata yang diikuti oleh huruf }}$ yang sama tidak berbeda nyata menurut uji jarak berganda Duncan pada taraf $5 \%$.

Pada Tabel 10 diketahui bahwa pemberian pupuk silika organik menunjukan pengaruh yang tidak berbeda nyata terhadap bobot biji per rumpun dan bobot biji per perlakuan. Hal ini diduga bahwa perlakuan pupuk silika organik yang diberikan butuh waktu untuk larut, sehingga tidak terdapat pengaruh terhadap bobot biji per rumpun dan bobot biji per perlakuan. Pada hasil analisis tanah awal kandungan Si dalam tanah sudah cukup tinggi yaitu sekitar 22,24\%, sehingga dapat diduga tidak terdapat pengaruh yang nyata pada tanah yang cukup Si jika diberikan pupuk silika organik.

Faktor lain yang juga mempengaruhi pengisian biji hanjeli yaitu ketersediaan unsur hara dalam tanah, seperti unsur fosfor (P). Pemberian pupuk silika organik secara tidak langsung meningkatkan ketersediaan P di dalam tanah yang disajikan pada Tabel 2. Hasil penelitian Zulputra $d k k$ (2014), menyatakan bahwa pemberian silikat dan pupuk fosfat dapat 
meningkatkan jumlah gabah per malai pada tanaman padi. Hal itu disebabkan kebutuhan hara P selama pembentukan gabah tercukupi. Sejalan dengan pernyataan (Hardjowigeno, 2003) bahwa tanaman membutuhkan unsur $P$ untuk pertumbuhan dan produksi terutama untuk bunga, buah, dan biji.

Bobot 100 Biji. Bobot 100 biji dapat dilihat pada Tabel 11. Pengaruh Pupuk Silika Organik terhadap Bobot 100 Biji Tanaman Hanjeli.

Tabel 11. Pengaruh Pupuk Silika Organik terhadap Bobot 100 Biji Tanaman Hanjeli.

\begin{tabular}{cc}
\hline \hline Perlakuan & Bobot 100 biji $(\mathrm{g})$ \\
\hline A & $15,19 \mathrm{a}$ \\
B & $13,44 \mathrm{a}$ \\
C & $13,88 \mathrm{a}$ \\
D & $14,44 \mathrm{a}$ \\
E & $13,63 \mathrm{a}$ \\
F & $15,00 \mathrm{a}$ \\
\hline \hline
\end{tabular}

Keterangan : Nilai rata-rata yang diikuti oleh huruf yang sama tidak berbeda nyata menurut uji jarak berganda Duncan pada taraf $5 \%$.

Hal ini diduga bahwa hasil dipengaruhi oleh ukuran biji karena hasil biji ukurannya hampir seragam pada setiap perlakuan, sehingga tidak menunjukkan berbeda nyata. Faktor yang juga mempengaruhi perlakuan tanpa silika (kontrol) lebih tinggi dibandingkan dengan perlakuan dengan pemberian pupuk silika organik ialah pada hasil analisis tanah awal kandungan Si dalam tanah sudah cukup tinggi yaitu sekitar 22,24\%, sehingga dapat diduga tidak terdapat pengaruh yang nyata pada tanah yang cukup Si jika diberikan pupuk silika organik. Faktor genetik juga mempengaruhi ukuran biji pada tanaman hanjeli. Hasil penelitian Rohimat (2014) menghasilkan bobot 100 biji sebesar 10,14-11,29 g, sehingga dapat dilihat bahwa pemberian pupuk silika organik berpengaruh terhadap bobot biji hanjeli meskipun hasilnya tidak berbeda nyata.

Rendemen Biji Pecah Kulit (RBPK) dan Kekerasan Biji. Rendemen biji pecah kulit merupakan perbandingan antara bobot biji pecah kulit dengan bobot biji berkulit, sedangkan kekerasan biji merupakan parameter yang diukur untuk mengetahui pengaruh pemberian pupuk silika terhadap kekerasan biji hanjeli dengan menggunakan alat penetrometer.

Pada Tabel 12 diketahui bahwa RBPK tertinggi terdapat pada perlakuan C (Silika dosis $9.00 \mathrm{~g} /$ tanaman), sedangkan kekerasan biji tertinggi terdapat pada perlakuan F (Silika dosis
$22.50 \mathrm{~g} /$ tanaman). Diduga bahwa dengan perlakuan pupuk silika organik membuat kulit biji hanjeli menjadi lebih keras dibandingkan dengan perlakuan kontrol.

Tabel 12. Pengaruh Pupuk Silika Rendemen Biji Pecah Kulit (RBPK) dan Kekerasan Biji Tanaman Hanjeli.

\begin{tabular}{ccc}
\hline \hline Perlakuan & $\begin{array}{c}\text { Rendemen biji } \\
\text { pecah kulit } \\
(\text { RBPK) }\end{array}$ & $\begin{array}{c}\text { Kekerasan biji } \\
\text { (lbf) }\end{array}$ \\
\hline A & 0,43 & 17,27 \\
B & 0,55 & 26,33 \\
C & 0,62 & 28,17 \\
D & 0,45 & 27,33 \\
E & 0,45 & 24,90 \\
F & 0,43 & 31,50 \\
\hline \hline
\end{tabular}

Hal ini sesuai dengan pernyataan Ratnawati (2005), bahwa Si yang tertimbun di dalam dinding sel buah tomat meningkatkan kekerasan buah, meningkatnya kandungan $\mathrm{Si}$ dalam kulit buah menyebabkan kulit buah menjadi semakin keras. Perbedaan akumulasi dan penyebaran $\mathrm{Si}$ dalam organ tanaman bersifat genetis berbeda pada setiap tanaman. Menurut Roesmarkam dan Nasih (2002), pada tanaman yang bersifat akumulator $\mathrm{Si}$, misalnya pada padi sebagian besar Si terdapat pada bagian tajuk tanaman.

Tabel 13. Hubungan antara Rendemen Biji Pecah Kulit (RBPK) dengan Kekerasan Biji Tanaman Hanjeli.

\begin{tabular}{cccccc}
\hline \hline & $\begin{array}{c}\text { Persamaan } \\
\text { Regresi }\end{array}$ & df & $\mathrm{R}^{2}$ & $\begin{array}{c}\text { Koefisien } \\
\text { Korelasi }\end{array}$ & $\mathrm{P}$ \\
& $\mathrm{Y}=$ & 5 & 0,0 & 0,26 & 0,6 \\
Kekerasa & $\mathrm{n} \mathrm{Biji}$ & $\begin{array}{c}15,73+18,24 \\
\mathrm{x}\end{array}$ & 7 & & 2 \\
& & & & \\
\hline \hline
\end{tabular}

Keterangan : df : Derajat Bebas $\mathrm{R}^{2}$ : Koefisien

Determinasi P : Signifikansi

Hasil Tabel 13 menunjukkan bahwa hasil analisis korelasi menunjukkan adanya derajat hubungan antara rendemen biji pecah kulit dengan kekerasan biji, yang ditandai dengan koefisien korelasi $(r=0,26)$, meskipun tidak signifikan yang ditandai dengan $(P)<0,05$. Hasil menunjukkan dimana setiap peningkatan rendemen biji pecah kulit akan diikuti kenaikan kekerasan biji.

Hasil analisis regresi menunjukkan model persamaan regresi linear yang terbentuk adalah $\left(Y=15,73+18,24 x ; R^{2}=0,07 ; P=0,62\right)$. Hasil 
menunjukkan bahwa besarnya kenaikan jumlah rendemen biji pecah kulit $(X)$ akan diikuti kenaikan jumlah kekerasan biji (Y).

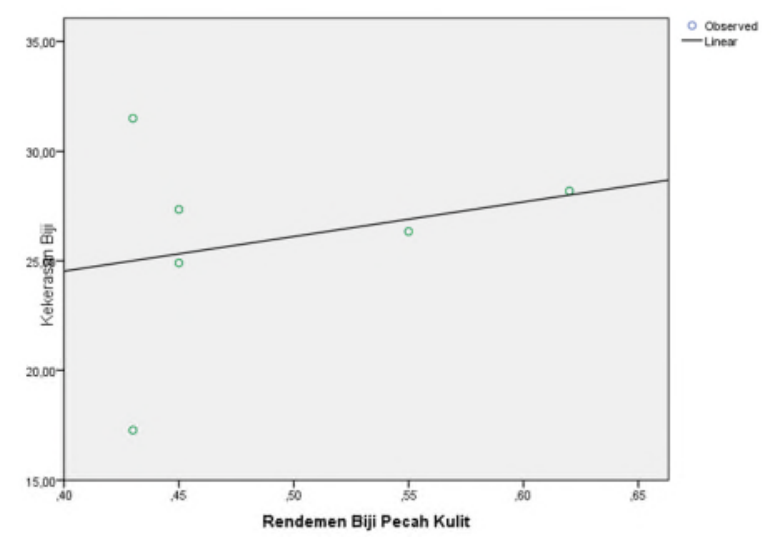

Gambar 1. Korelasi antara Rendemen Biji Pecah Kulit (RBPK) Dengan Kekerasan Biji

Indeks Panen. Indeks panen merupakan perbandingan bobot kering biji dibagi dengan bobot kering biomassa tanaman. Berdasarkan hasil analisis data statistik yang disajikan pada Lampiran 28 diketahui bahwa pemberian pupuk silika menunjukkan pengaruh yang berbeda nyata pada setiap perlakuan terhadap indeks panen.

Tabel 14. Pengaruh Pupuk Silika Organik terhadap Indeks Panen Tanaman Hanjeli.

\begin{tabular}{cc}
\hline \hline Perlakuan & Indeks Panen \\
\hline A & $0,32 \mathrm{a}$ \\
B & $0,41 \mathrm{a}$ \\
C & $0,28 \mathrm{a}$ \\
D & $0,37 \mathrm{a}$ \\
E & $0,45 \mathrm{a}$ \\
F & $0,34 \mathrm{a}$ \\
\hline
\end{tabular}

$\overline{\text { Keterangan : Nilai rata-rata yang diikuti oleh huruf }}$ yang sama tidak berbeda nyata menurut uji jarak berganda Duncan pada taraf $5 \%$.

Pada Tabel 14 diketehui bahwa pemberian pupuk silika organik menunjukan pengaruh yang tidak berbeda nyata terhadap indeks panen tanaman hanjeli. Hal ini diduga karena pupuk silika organik belum sepenuhnya terlarut pada tanaman hanjeli, meskipun hasil menunjukkan bahwa perlakuan pemberian pupuk silika organik menghasilkan indeks panen yang lebih baik. Pada hasil analisis tanah awal kandungan Si dalam tanah sudah cukup tinggi yaitu sekitar 22,24\%, sehingga dapat diduga tidak terdapat pengaruh yang nyata pada tanah yang cukup Si jika diberikan pupuk silika organik. Indeks panen menggambarkan proporsi fotosintat yang ditranslokasikan ke dalam bagian penyimpanan cadangan makan. Fotosintat yang dihasilkan daun ditranslokasikan ke bagian cadangan makanan dalam bentuk biji. Semakin tinggi nilai Semakin tinggi nilai indeks panen menunjukkan bahwa fotosintat ditajuk banyak ditranslokasi ke bagian biji yang menghasilkan hasil biji yang besar, sehingga berpengaruh nyata terhadap hasil indeks panen.

\section{Kesimpulan dan Saran}

1. Pemberian pupuk silika organik berpengaruh terhadap biomassa total tanaman, tetapi tidak berpengaruh terhadap tinggi tanaman, jumlah daun, jumlah anakan per rumpun dan indeks luas daun tanaman hanjeli.

2. Pemberian pupuk silika organik dengan dosis 9,00 g/tanaman, 13,50 g/tanaman dan $22,50 \mathrm{~g} /$ tanaman memberikan hasil yang sama dengan perlakuan tanpa pupuk silika pada biomassa tanaman total.

3. Terdapat hubungan antara rendemen biji pecah kulit (rbpk) dengan kekerasan biji $(\mathrm{r}=$ $0,26)$, dimana semakin meningkat rendemen biji pecah kulit akan diikuti kenaikan kekerasan biji.

4. Pemberian pupuk silika organik pada penelitian selanjutnya diberikan dalam bentuk arang sekam yang sudah dihaluskan atau dalam bentuk larutan dan diberikan bersamaan dengan pemberian pupuk dasar yang dilakukan di lahan, sehingga diharapkan lebih mudah terlarut dan diserap oleh tanaman hanjeli.

\section{Daftar Pustaka}

Amrullah. 2015. Pengaruh Nano Silika terhadap Pertumbuhan, Respon Morfofisiologi dan Produktivitas Tanaman Padi (Oryza sativa L.). Tersedia di http://repository.ipb.ac.id/ handle/123456789/74526. (Diakses pada 28 April 2015)

Gardner, F.P, R.B. Perace dan R.L. Mitchell. 1991. Fisiologi Tanaman Budidaya. Penerjemah: Susilo, H. UI Press, Jakarta.

Grubben, G. J. H dan S. Partohardjono. 1996. Plant Resources of South - East Asia. Prosea. Bogor.

Hardjowigeno, S dan Widatmaka. 2007. Evaluasi Kesesuaian Lahan dan Perencanaan Tataguna Lahan. Bogor. Gadjah Mada University Press. Yogyakarta. 
Ma JF and Takashi E. 2002. Soil, Fertilizer and Plant Silicon, Research Elsevier Science B. $\mathrm{V}$, Amsterdam.

Ratnawati. 2005. Pemnafaatan Limbah PLTU Paiton sebagai Sumber Silika Alami dalam rPeningkatan Hasil dan Kualitas Bauh Tomat (Lycopersion esculentum Mi.). Universitas Jember, Jember.

Roesmarkam, N dan W. Yuwono. 2002. Ilmu Kesuburan Tanah. Kanisius, Yogyakarta.

Rohimat, Ujang. 2014. Pengaruh Pupuk Kalium dan Fungi Mikoriza Arbuskula terhadap Pertumbuhan dan Hasil Tanaman Hanjeli (Coix lacryma jobi L.) pada lahan sawah. Fakultas Pertanian, Universitas Padjadjaran, Jatinangor. (Tidak dipubilkasi).

Solichatun, Endang Anggarwulan dan Widya Mudyantini. 2005. Pengaruh Ketersediaan Air terhadap Pertumbuhan dan Kandungan Bahan Aktif Saponin Tanaman Ginseng Jawa (Talinum paniculatum Gaertn.). Biofarmasi 3 (2): 47-51. Jurusan Biologi FMIPA UNS, Surakarta.
Sudibyo, B. S. B. 2008. Pengaruh Pemberian Si terhadap Serapan Si dan Hasil Jagung (Zea mays,. L) Pada Andisol. Skripsi Sarjana S1 Fakultas Pertanian UGM, Yogyakarta.

Warta Penelitian dan Perkembangan Pertanian. 2011. Sumber Hara Silika untuk Pertanian. Vol. 33 (3). Tersedia online di http:// pustaka.litbang.pertanian.go.id/publikasi/ wr333116.pdf. (Diakses pada 12 Mei 2015)

Yelis, R. 2011. Peningkatan Produktivitas Hanjeli Indigenous Kiara Payung Sebagai Pangan Bergizi Dengan Pemberian Pupuk N, P, K Pada Dosis dan Waktu yang Berbeda. Budidaya Pertanian. Faperta Universitas Padjadjaran, Jatinangor. (Tidak dipublikasikan).

Zulputra, Wawan dan Nelvia. 2014. Respon Padi Gogo (Oryza sativa L.) terhadap Pemberian Silikat dan Pupuk Fosfat Pada Tanah Ultisol. Jurnal Agroteknologi, Vol. 4 (2). Fakultas Pertanian Universitas Riau, Riau. 